\title{
MNA as a Remedy for Arsenic Mobilized by Anthropogenic Inputs of Organic Carbon
}

\author{
by Janet G. Hering, Peggy A. O'Day, Robert G. Ford, Y. Thomas He, Azra Bilgin, H. James Reisinger, and \\ David R. Burris
}

\begin{abstract}
The potential application of monitored natural attenuation (MNA) as a remedy for ground water contaminated with arsenic (As) is examined for a subset of contaminated sites, specifically those where naturally occurring As has been mobilized due to localized anthropogenic organic carbon (OC) releases. This includes sites subject to petroleum releases, exposure to landfill leachates, and $\mathrm{OC}$ additions for biostimulation of reductive dechlorination of chlorinated solvents. The key characteristic of these sites is that, under conditions prevailing before the anthropogenic OC introduction, the naturally occurring As in the subsurface was not mobile and did not adversely affect ground water quality. This suggests that, in the far-field (where background conditions are (re) established), As may be sequestered upon contact of the contaminated ground water with either or both the (uncontaminated) ambient ground water and the background aquifer minerals. The observed extents of elevated concentrations (or "footprints") of As and other chemical species, such as dissolved OC and iron (Fe), and related parameters, such as redox potential $\left(E_{\mathrm{h}}\right)$ and dissolved oxygen, and their evolution over time can be used to assess the mobilization and sequestration of As and the potential feasibility of MNA as a remedial option. Ultimately, the capacity for As sequestration must be assessed in the context of the OC loading to the site, which may require "active" measures for source control. Monitoring is needed to confirm the continuing effectiveness of the MNA remedy or to indicate if contingency measures must be implemented.
\end{abstract}

\section{Introduction}

The conceptual and technical basis for the possible application of MNA (monitored natural attenuation) as a knowledge-based remedy for ground water plumes of inorganic contaminants has been recently elaborated by the U.S. Environmental Protection Agency (USEPA 2007a). This application of MNA relies in part on the successes of this remedy for organic contaminants in ground water but must take into account the different types of natural attenuation processes applicable to inorganic and organic contaminants (Rittmann et al. 2007). Specific assessment has also been provided for arsenic (As); this element was chosen for assessment partly on the basis of its widespread occurrence as a contaminant of concern at Superfund sites (USEPA 2007b).

The biogeochemical processes that can contribute to the natural attenuation of As (Table 1) are, in the general case, well established (USEPA 2007b; Ghosh et al. 2003; Lin and Puls 2003; NRC 2000; Reisinger et al. 2005; Stollenwerk and Colman 2003; Wang and Mulligan 2006; McMahon and

Copyright $\odot 2009$ The Author(s)

Journal compilation @ 2009 National Ground Water Association.
Chapelle 2008; Welch and Lico 1988; Welch et al. 1988, 2000; Hering and Kneebone 2001). For elemental inorganic contaminants that do not undergo radioactive decay (such as As), immobilization by precipitation, coprecipitation, or sorption are key mechanisms to protect environmental receptors. It is a critical consideration in MNA for such inorganic contaminants that the contaminant remains immobile in the subsurface. The long-term stability of immobilized As is thus a requirement for successful MNA.

Site- and parameter-specific characterization is an essential component of MNA, from the perspective of both establishing the feasibility of MNA at a specific site and ensuring its long-term viability. The EPA documents (USEPA 2007a, 2007b) describe a tiered approach through which site characterization tasks can be organized to reduce uncertainty in remedy selection and manage costs. The four tiers are (1) demonstration of active contaminant removal from ground water and dissolved plume stability, (2) determination of the rate and mechanism of attenuation, (3) determination of the long-term capacity for attenuation and stability of immobilized contaminants, and (4) design of performance monitoring program, including defining triggers for assessing MNA failure, and establishing a contingency plan. 


\begin{tabular}{|c|c|}
\hline \multicolumn{2}{|c|}{$\begin{array}{l}\text { Table } 1 \\
\text { Natural Attenuation Processes Applicable to Arsenic } \\
\text { (USEPA 2007b) }\end{array}$} \\
\hline Process & $\begin{array}{l}\text { Potential Effect on Arsenic in } \\
\text { Subsurface }\end{array}$ \\
\hline Biotransformation & $\begin{array}{l}\text { Redox cycling of arsenic affects } \\
\text { mobility } \\
\text { Methylation of arsenic affects } \\
\text { mobility and toxicity } \\
\text { Reduction to arsine } \\
\text { arsines) increases volatility }\end{array}$ \\
\hline Dilution/dispersion ${ }^{3}$ & Reduces contaminant concentration \\
\hline Precipitation & Immobilization/stabilization \\
\hline Sorption & Immobilization/stabilization \\
\hline Volatilization & $\begin{array}{l}\text { Transfer of arsine }{ }^{1} \text { and methylated } \\
\text { arsines from subsurface }\end{array}$ \\
\hline \multicolumn{2}{|c|}{$\begin{array}{l}{ }^{1} \text { Unlikely to be significant at contaminated sites. } \\
{ }^{2} \text { Note that arsine is extremely toxic. } \\
{ }^{3} \text { Note that EPA discourages reliance on processes of dilution and dispersion, } \\
\text { which decrease the concentration but not the mass of contaminants. }\end{array}$} \\
\hline
\end{tabular}

It is clear that MNA will not be an appropriate option for all sites with inorganic contaminants. At some sites, MNA may be combined with other "active" remedial methods to achieve site-specific remedial objectives (USEPA 2007a). In particular, MNA may be suitable as a "polishing" step after, for example, active remediation of a contaminant source.

Here, we consider the potential suitability of MNA for application to a particular subset of As-contaminated sites, specifically sites where naturally occurring As has been mobilized by the anthropogenic introduction of organic carbon (OC). The key characteristic of these sites is that, under ambient conditions (i.e., the conditions prevailing before the anthropogenic OC introduction), the naturally occurring As in the subsurface was not mobile and did not adversely affect ground water quality. Ambient conditions may be assessed upgradient of the OC introduction or in the far-field, downgradient of the influence of the OC inputs. The immobility of naturally occurring As under ambient conditions may, in such cases, be an indication for the potential success of MNA as a remedy for As-contaminated ground water. This potential application of MNA is considered in the context of a conceptual site model that relates the processes of As mobilization and sequestration to the conditions prevailing at the site.

\section{Anthropogenic Inputs of Organic Carbon as a Driver for Arsenic Mobilization}

In many soils and aquifer sediments, naturally occurring As is associated with iron-bearing minerals. This is particularly the case for alluvial sediments where As is deposited during secondary mineral formation (McMahon and Chapelle 2008; Welch et al. 1988, 2000). In shallow, aerobic, uncontaminated aquifers, iron (Fe) is present primarily as Fe(III) oxyhydroxides (Schwertmann and Taylor 1989). Because these phases undergo reductive dissolution, the As associated with them can be mobilized under reducing conditions (Lee et al. 2005; Zobrist et al. 2000; Cummings et al. 1999). The reductive dissolution of Fe(III) oxyhydroxide phases in soils and sediments is generally attributed to microbial processes, which are supported by OC as a substrate for heterotrophic respiration (Cummings et al. 1999; Roden 2003, 2004, 2006; Cooper et al. 2005; Bonneville et al. 2004; Glasauer et al. 2003; Benner et al. 2002; Lovley et al. 1989; Lovley 1987; Lovley and Phillips 1986a, 1986b; Albrechtsen et al. 1995). The characteristic zonation in oxidation-reduction (redox) potential that develops downgradient of an OC source reflects the shift to progressively less favorable electron acceptors (i.e., from consumption of dissolved oxygen [DO] in oxidative respiration to, eventually, fermentation) (Cozzarelli et al. 2001; Christensen et al. 2000, 2001; Heron et al. 1998). Note that because As can also be sequestered in the form of authigenic sulfide minerals and can also form dissolved thioarsenite complexes, the mobility of As under reducing conditions will reflect not only the redox potential but also the concentrations of $\mathrm{Fe}$ and sulfur (S) in the ground water (Lee et al. 2005; Keimowitz et al. 2007; Demergasso et al. 2007; O'Day et al. 2004; Bostick and Fendorf 2003; Newman et al. 1997; Rittle et al. 1995; Beak et al. 2008; Kirk et al. 2004; Mukherjee and Fryar 2008). In most fresh water aquifers (excepting those affected by sea water intrusion or infiltration of high-sulfate mine waters or waste waters), As removal by this precipitation mechanism is limited by sulfate availability.

Mobilization of naturally occurring As has been observed at a variety of sites subjected to anthropogenic OC inputs. These inputs derive from leakage of petroleum hydrocarbons from storage facilities or pipelines (Ghosh et al. 2003; Reisinger et al. 2005; Stollenwerk and Colman 2003; Burgess and Pinto 2005), generation of organic-rich leachates at sanitary landfills (Reisinger et al. 2005; Stollenwerk and Colman 2003; deLemos et al. 2006; Keimowitz et al. 2005; Pinel-Raffaitin et al. 2007), and the intentional introduction of OC to enhance the in situ reductive dechlorination of chlorinated solvents (McLean et al. 2006; Suthersan and Horst 2008). Significant mobilization of naturally occurring As, resulting in As concentrations in ground water exceeding $100 \mu \mathrm{g} / \mathrm{L}$ and, in some cases, even $1 \mathrm{mg} / \mathrm{L}$, has been observed in each of these site types. In the case of landfills, however, disposal of As-containing wastes in the landfill itself may also contribute to the plume of As-contaminated ground water that develops downgradient of the landfill. Leaching of As from chromated copper arsenate (CCA)-treated wood has been observed under landfill conditions (Jambeck et al. 2006, 2007; Moghaddam and Mulligan 2008; Saxe et al. 2007; Townsend et al. 2004). It is anticipated that disposal of As-bearing solid residuals from water treatment will increase As loading to landfills, with the potential for reductive mobilization (Ghosh et al. 2004; Jing et al. 2005)

Because, in these cases, the input of $\mathrm{OC}$ is the driver for the mobilization of naturally occurring As, two obvious question arise. The first is whether and when the mobilization of As would cease if the OC inputs were to be halted. The second is whether the As already mobilized in the ground water will undergo natural attenuation as the plume moves away from the area directly affected by the input of 
OC. To assess this second question, a brief review of the As sequestration mechanisms that are potentially relevant to such situations is warranted.

\section{Far-Field Conditions and the Potential for Natural Attenuation of As}

In the cases considered here, it is a precondition that the naturally occurring As was immobile before the introduction of anthropogenic OC (i.e., under ambient conditions). These conditions must, by definition, prevail in the far-field (i.e., the area sufficiently far downgradient of the OC source to be unaffected by it). At the leading edge of the plume, the contaminated ground water (whose composition has been altered by the microbial respiration of anthropogenic OC) comes into contact both with the ambient ground water and with the ambient aquifer materials. The immobility of As under ambient conditions, however, does not necessarily imply that the As transported with the contaminated plume of ground water will be effectively sequestered onto the aquifer materials with which it comes into contact. The potential effectiveness of such sequestration must be evaluated on a site-specific basis, taking into account both the nature of the ambient aquifer material and the composition of the As-contaminated ground water plume as well as the transport properties of the aquifer.

\section{Relevant Sequestration Mechanisms}

Precipitation, coprecipitation, and sorption are the dominant potential sequestration processes for As. The gradients in chemical composition of ground water and in redox conditions that occur at the plume boundary can lead to precipitation reactions, particularly the oxidation of $\mathrm{Fe}(\mathrm{II})$ and its precipitation as $\mathrm{Fe}(\mathrm{III})$ oxyhydroxides (Cozzarelli et al. 2001; Vencelides et al. 2007). These freshly precipitated solids can then serve as substrates for the sorption and/or coprecipitation of As (Hohn et al. 2006). This behavior has been observed in laboratory studies where oxygen $\left(\mathrm{O}_{2}\right)$ was introduced into a suspension of aquifer solids from which As and $\mathrm{Fe}$ had been mobilized under reducing conditions (Radloff et al. 2007). In addition, As can be sorbed onto native aquifer materials in the far-field. Iron oxyhydroxides would be expected to be a major contributor to As sequestration, followed by clay and feldspars (Lin and Puls 2003). The sorption of As onto naturally occurring geologic materials has been reviewed by Smedley and Kinniburgh (2002).

The sequestration of As can be influenced by changes in its oxidation state. Although both $\mathrm{As}(\mathrm{III})$ and $\mathrm{As}(\mathrm{V})$ can be immobilized by sorption onto Fe(III) oxyhydroxides, the extent of As sorption, particularly in the presence of competing sorbing anions such as phosphate, can be strongly influenced by its oxidation state (Dixit and Hering 2003). In the case of other sorbents, particularly aluminum (Al) oxyhydroxides and aluminosilicates, As(III) is much less effectively sorbed than As(V) (Hering and Dixit 2005; Goldberg and Johnston 2001). Both As(V) and As(III) can be present in contaminated ground water even under reducing conditions. At the plume boundary, As(III) may be oxidized by reaction with minerals containing manganese $(\mathrm{Mn})$ in the +III or +IV oxidation state (Amirbahman et al. 2006; Deschamps et al. 2005; Manning et al. 2002, 2003; Manning and Suarez 2000; Chiu and Hering 2000; Scott and Morgan 1995; Oscarson et al. 1981, 1983) or by radical species generated during the oxidation of $\mathrm{Fe}$ (II) by $\mathrm{O}_{2}$ (Hug and Leupin 2003). Direct oxidation of $\mathrm{As}(\mathrm{III})$ by $\mathrm{O}_{2}$ is kinetically limited at circumneutral $\mathrm{pH}$ but can occur rapidly due to microbial mediation (Oremland and Stolz 2003; Salmassi et al. 2002).

The extent of As sequestration will depend on a number of parameters, including (1) the nature and surface area of potential sorbents (either pre-existing or freshly precipitated); (2) the composition of the contaminated ground water (including $\mathrm{pH}$, concentrations of As and competing sorbates); (3) concentrations of $\mathrm{Fe}(\mathrm{II})$ and $\mathrm{Mn}(\mathrm{II})$, which could form fresh sorbent surfaces upon oxidative precipitation; (4) the kinetics of sorption and precipitation reactions, particularly relative to ground water flow velocities; and (5) the concentrations of OC, which could destabilize Fe(III) or $\mathrm{Mn}(\mathrm{III}, \mathrm{IV})$ minerals present in the far-field.

One challenging issue is whether it is reasonable to expect that direct evidence of As sequestration can be obtained by the examination of aquifer sediments collected from a putative sequestration zone. Particularly at sites where the mobilization of naturally occurring As is the source of ground water contamination, the background content of As in the aquifer sediments may be sufficiently high, or of similar speciation, to obscure the signature of sequestered As. In such cases, laboratory studies conducted with aquifer sediments may provide the basis for identification of probable sequestration mechanisms, estimation of sequestration capacity, and evaluation of the stability of immobilized As under plume conditions (Choi et al. 2009).

A key point is that, as the plume advances, a region that had been at the leading edge of the plume (where prevailing gradients may have favored As sequestration) will then be exposed to the contaminated ground water in the body of the plume, which may result in remobilization of the previously sequestered As. As long as the plume transports sufficient OC for microbial respiration, As sequestered at the leading edge of the plume may be remobilized when the organic-rich ground water reaches the site of sequestration. Although As toxicity to the microbial community could, in principle, limit microbial respiration of OC, microbes have evolved a variety of modes of As resistance (Mukhopadhyay et al. 2002). Hypertolerant bacteria have been isolated that are resistant to $\mathrm{As}(\mathrm{III})$ at concentrations up to $0.9 \mathrm{~g} / \mathrm{L}$ (i.e., $9 \times 10^{5} \mu \mathrm{g} / \mathrm{L}$ ) and even higher concentrations of $\mathrm{As}(\mathrm{V})$ (Drewniak et al. 2008). Therefore, the dynamics of the evolution of ground water composition (specifically with regard to the concentrations of target contaminants at the point of compliance) must explicitly consider the "driver" for As mobilization in the cases at issue, that is, the introduced OC.

\section{Considerations of the Dynamics of Plume Evolution in MNA Application}

In the cases where naturally occurring As is mobilized by the anthropogenic OC introduction, MNA poses some 
different issues depending on whether the introduction was intentional or inadvertent. If the OC introduction is (or was) intentional and of limited duration (e.g., for biostimulation of in situ contaminant degradation), then it may be possible to rely on MNA to protect receptors from As mobilized in and near the treatment zone if the mobilized As is subsequently sequestered before the ground water reaches the receptor. The MNA remedy must take into account that, even after the biostimulation is completed and OC introduction is halted, the introduced OC will continue to be mineralized (until its exhaustion) by microbial oxidation, thus driving the reductive dissolution of $\mathrm{Fe}(\mathrm{III})$ oxyhydroxides and mobilization of As during that timeframe. In the case of intentional OC introduction, the amount and duration of the organic loading should be known. The aquifer system must have sufficient capacity to sequester As mobilized both during and after the active period of biostimulation. If the introduction of $\mathrm{OC}$ was inadvertent, then two additional questions arise: (1) Can the total OC loading to the system, and hence the demand on the sequestration capacity of the aquifer, be reasonably estimated? and (2) Has (or can) the primary OC source be removed or contained such that the "driver" for As mobilization can be reasonably expected to diminish over time?

Because, in the cases under consideration, As derives from natural sources, it is important to define various boundaries (or "footprints") within the plume according to a series of criteria. Specifically, there are footprints associated with (1) the maximum possible extent of the plume in the absence of attenuation by biogeochemical processes (i.e., as if a conservative tracer was present when $\mathrm{OC}$ was introduced); (2) the $\mathrm{OC}$ as it is introduced and undergoes mineralization; (3) arsenic as it undergoes sequential (and possibly multiple) processes of mobilization and sequestration; and (4) other redox-active species that may influence either the mobilization or the sequestration of As or serve as indicators of the continued influence of the evolving plume on subsurface redox conditions. Comparison of these footprints and of their evolution over time should provide empirical insight into the behavior of As in the subsurface system.

\section{Need for Active Remediation of the Organic Carbon Source}

Because the introduced $\mathrm{OC}$ is the driver for As mobilization in the systems of interest, the bioavailability, persistence, and fate of the OC itself must be explicitly considered in the evaluation of MNA as a remedy for As contamination. Over time, OC mineralization should decrease its concentration. Thus, if fresh OC is not continually supplied, the microbial activity that results in the reductive dissolution of Fe(III) oxyhydroxides and As mobilization will also diminish. If the source of the introduced OC is sufficiently limited and localized, active remediation of the OC source may not be required for As MNA to be successful.

In cases of inadvertent introduction of $\mathrm{OC}$, however, it is likely that active remediation of the $\mathrm{OC}$ source would be necessary for As MNA to succeed. The most appropriate method for active remediation of the $\mathrm{OC}$ source will depend on its nature and extent. For petroleum hydrocarbons, active remediation of the source area could include free product recovery, excavation, bioventing, biosparging, and soil vapor extraction (Khaitan et al. 2006). The loading of OC from landfills can be minimized by capping, physical hydraulic barriers, landfill aeration, and leachate collection systems (Christensen et al. 1994, 2001). The active remediation of the OC source must be sufficient to prevent the NA capacity of the aquifer system for As from being overwhelmed. The need for active remediation of the OC source may be reassessed over time on the basis of the observed effectiveness of As MNA.

\section{Illustrative Footprints for the Evaluation of As MNA}

An examination of the footprints of As and other chemical species (or related parameters) at a contaminated site can provide insight into the processes of As mobilization and sequestration and indicate whether the behavior of As conforms to the conceptual model developed for the site under consideration. As an illustration, we consider a site, Devens Reserve Forces Training Area (Devens, Massachusetts), where the mobilization of naturally occurring As was observed following the introduction of OC (as molasses) to promote the reductive dechlorination of tetrachloroethylene (He et al. submitted). The molasses injection area in this study is located approximately $610 \mathrm{~m}$ (2000 feet) downgradient of the PCE source area. The PCE plume is relatively narrow as determined by a monitoring well network, and the molasses injection area encompassed the lateral extent of the plume; the downgradient monitoring wells (Figure 1) were within the PCE plume. Depth to the water table was approximately $18 \mathrm{~m}$ (60 feet). The lower bounds of the 3-m (10-feet) well screen intervals were at approximately $41 \mathrm{~m}$ (135 feet) below ground surface at the boundary between the glacio-fluvial deposits and the underlying glacial till. Vertical ground water sampling indicated that the PCE plume was located just above the glacial till. Monthly injections of molasses solution at this depth were initiated in December 2001 and continued through 2006; illustrative footprints are shown for sampling events in January 2003 and May 2006 (Figure 1).

Additional monitoring wells were installed before the May 2006 ground water sampling. The additional data gained from these newly installed monitoring wells are not reflected in the January 2003 contours. Thus, the comparison of the January 2003 and May 2006 contours must take into account the improved delineation of the plume at the later sampling event.

The footprint of As itself, of course, provides key information for assessing the extent of As mobilization and sequestration and evaluating the feasibility of MNA as a remedy. At Devens, low dissolved As concentrations $(<10 \mu \mathrm{g} / \mathrm{L})$ are observed upgradient of the injection area and in the far-field downgradient, beyond the influence of the OC plume. This indicates that, in the absence of introduced OC, naturally occurring As at this site is immobile.

The January 2003 footprints indicate that reducing conditions were rapidly established at the site downgradient of 

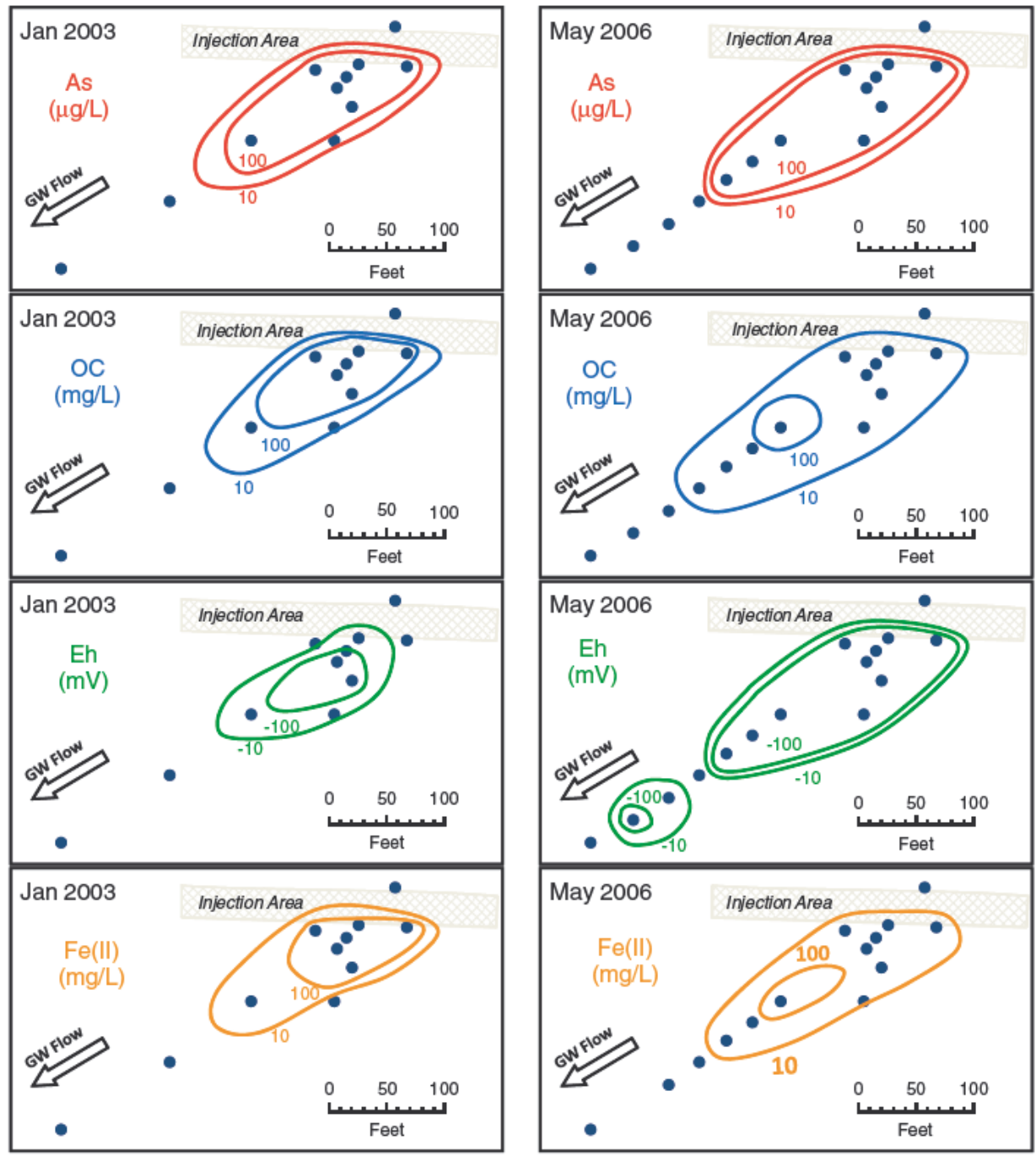

Figure 1. Footprints of dissolved As, dissolved OC, $E$, and dissolved Fe at a reductive dechlorination biostimulation site, Devens Reserve Forces Area, Massachusetts. The area of injection of the molasses solution and location of monitoring wells (solid dots) are indicated. Ground water flow rate is approximately $\sim 0.34 \mathrm{~m} / \mathrm{day}(\sim 1.1 \mathrm{feet} /$ day $)$. Left panels: January 2003 . Right panels: May 2006 (He et al. submitted). Note: In the $2006 E_{\mathrm{h}}$ graph, the well between the two negative $E_{\mathrm{h}}$ lobes has a slightly positive $E_{\mathrm{h}}(19 \mathrm{mV})$.

the molasses injection area. Elevated dissolved As concentrations were observed to coincide with reducing conditions (as indicated by low redox potential $\left(E_{\mathrm{h}}\right)$ and elevated dissolved $\mathrm{Fe}(\mathrm{II})$ concentrations) and with elevated dissolved OC concentrations. Note that $E_{\mathrm{b}}$ is shown because of its common use as a field parameter and to provide a qualitative description of redox conditions; quantitative interpretations of field-measured $E_{\mathrm{h}}$ can be problematic (Grenthe et al. 1992). Although DO is also a commonly measured field parameter, its concentration at this site was too low to be a useful indicator of redox conditions. The extents of these footprints are roughly comparable, confirming that both As and Fe are mobilized by the introduction of OC. This is consistent with As mobilization being a consequence of the reductive dissolution of $\mathrm{Fe}$ (III) oxyhydroxides driven by mineralization of the injected OC.

Approximately 3 years later, the May 2006 footprints show expansion downgradient for all parameters, which are again observed to be roughly comparable in extent. The average ground water velocity over the 2003 to 2006 period is estimated to be approximately $0.34 \mathrm{~m} /$ day ( 1.1 feet/day). Between January 2003 and May 2006, the leading edge of the As plume migrated approximately $12 \mathrm{~m}$ (40 feet), which is substantially less than the approximately $290 \mathrm{~m}$ ( 950 feet) estimated for ground water movement over that period (note that the distance of the As plume migration is approximate because of the lower resolution in the 2003 data as compared with 2006 when additional monitoring wells were available). Although this assumes that the contaminant plume did not somehow bypass the sampling locations, the monitoring of the chlorinated solvent plume (not shown) indicates that the monitoring wells are appropriately located. Ideally, the footprint of a conservative tracer introduced with the OC could be used to verify the ground water flowpath. In all cases, an adequate understanding of the site hydrogeology, including the direction and velocity of ground water flow, is a prerequisite for establishing the feasibility of MNA. In particular, the possibilities of preferential flowpaths should be carefully considered, and appropriate caution should be exercised in fracture flow regimes. 
The apparent retardation of dissolved $\mathrm{OC}, \mathrm{As}$, and $\mathrm{Fe}$ with respect to ground water movement suggests that, as the $\mathrm{OC}$ is mineralized, the dissolved $\mathrm{As}$ and $\mathrm{Fe}$ at the leading edge of the plume undergo sequestration upon contact of the contaminated ground water with either or both the (uncontaminated) ambient ground water and the background aquifer minerals. In the context of continuing OC injections, however, the long-term stability of sequestered $\mathrm{As}$ and $\mathrm{Fe}$ must be carefully evaluated. Although the NA capacity of the aquifer appears to be sufficient, in the near term, to retard As migration under the current OC loading, it is also necessary that it be sufficiently protective in the long term when OC inputs are discontinued (after the remediation of the chlorinated solvents is completed). Continued ground water monitoring and analysis of plume stability (Aziz et al. 2003) are necessary to ensure protection of downgradient receptors and to trigger implementation of contingency measures if needed.

Although not shown here, the footprints of additional species may be useful in understanding As mobilization and sequestration. The footprint of dissolved manganese (Mn) can be useful because Mn(III,IV) oxides undergo reductive dissolution under less strongly reducing conditions than do $\mathrm{Fe}(\mathrm{III})$ oxyhydroxides, and at the leading edge of the plume, dissolved $\mathrm{Fe}$ (II) can be oxidatively precipitated upon reaction with $\mathrm{Mn}(\mathrm{III}, \mathrm{IV})$ oxides present in the background matrix of aquifer minerals. Changes in ratio of dissolved $\mathrm{Mn}$ and $\mathrm{Fe}$ (i.e., comparison of the $\mathrm{Mn}$ and $\mathrm{Fe}$ footprints) may provide insight into the spatial distribution of these processes.

The footprint of dissolved phosphate can be informative because the geochemical behavior of phosphate is similar to that of arsenate, $\mathrm{As}(\mathrm{V})$, particularly with respect to sorption and precipitation. Elevated phosphate concentrations can increase As mobility through competitive sorption; thus, changes in phosphate concentrations may be indicative of processes that can also influence As occurrence.

Within the footprint of As itself, information on the distribution of $\mathrm{As}(\mathrm{III})$ and $\mathrm{As}(\mathrm{V})$ can also be useful. Although both $\mathrm{As}(\mathrm{III})$ and $\mathrm{As}(\mathrm{V})$ can be sequestered through sorption, their sorption behavior depends differently on ground water composition (i.e., $\mathrm{pH}$ and the concentration of competing sorbates) and the types of aquifer minerals. Knowledge of the chemical speciation of dissolved arsenic is needed to ascertain the mechanism controlling As immobilization and constraints on the capacity for attenuation.

Other useful footprints include those of sulfate, nitrate, and methane. The sulfate footprint can be used to determine whether sulfate reduction is occurring and whether sulfide minerals may be forming. The incorporation of As into sulfide minerals can provide an additional pathway for NA of As. Nitrate and methane footprints provide additional information on the redox zonation within the plume and the extent to which redox conditions in the plume have evolved through consumption of the anticipated series of electron acceptors.

\section{Conclusions}

Even when NA processes have been shown to be effective in sequestering As at a specific site, continued monitoring is a crucial component of the MNA remedy. Monitoring is needed to confirm the continuing effectiveness of the MNA remedy until such time as regulatory compliance levels are reached across the site. In addition, indirect evidence for NA (i.e., low concentrations of As downgradient of the presumed sequestration zone) should be supported by direct characterization of the mass and chemical speciation of sequestered As. If the signature of sequestered As is obscured by the background of naturally occurring As in the aquifer sediment, a basis for assessment of As sequestration capacity under plume conditions and the long-term stability of immobilized As may be provided by laboratory experiments with aquifer sediments. In any event, contingency plans must be implemented if monitoring indicates that NA processes are not sufficient to limit As migration.

A contingency plan is an integral part of the MNA remedy, which is implemented only if NA processes prove to be inadequate. For sites where naturally occurring As is mobilized by the introduction of $\mathrm{OC}$, in situ air sparging and the introduction of alternative oxidants into the aquifer downgradient of the leading edge of the plume are likely contingency plans. This would, in effect, constitute an augmentation of the NA processes that are expected to sequester As.

MNA may be an effective remedial option for sites where naturally occurring As has been mobilized due to localized introduction of OC. The zero-order question relevant to these sites is whether As was immobile under ambient conditions (i.e., before the introduction of OC). This question can be answered affirmatively if dissolved As concentrations in ground water are low upgradient of the OC inputs and/or in the far-field downgradient of the influence of the OC plume. The first-order questions that must be subsequently addressed include: (1) Is As in the plume undergoing attenuation? (2) What is the capacity for As sequestration in the near- and far-field?, and (3) What is the long-term stability of As sequestered in the near- and farfield? Examination of MNA footprints and their evolution over time, particularly the comparison of As migration with migration of a conservative tracer as observed or estimated based on ground water movement, should provide a basis for determining whether the migration of As is being retarded through sequestration processes and insight into the conditions that promote its mobilization and sequestration. Ultimately, the capacity for As sequestration must be assessed in the context of the OC loading to the site, which must be limited in duration (for intentional OC introduction) or controlled (for inadvertent $\mathrm{OC}$ introduction) if the As sequestration capacity of the aquifer system is not to be overwhelmed.

\section{Acknowledgments}

Support provided by the Strategic Environmental Research and Development Program (SERDP), project \#ER1374 , is gratefully acknowledged.

\section{References}

Albrechtsen, H.J., G. Heron, and T.H. Christensen. 1995. Limiting factors for microbial $\mathrm{Fe}(\mathrm{III})$-reduction in a landf 11 leachate 
polluted aquifer (Vejen, Denmark). FEMS Microbiology Ecology 16, no. 3: 233-247.

Amirbahman, A., D.B. Kent, G.P. Curtis, and J.A. Davis. 2006. Kinetics of sorption and abiotic oxidation of arsenic(III) by aquifer materials. Geochimica Et Cosmochimica Acta 70, no. 3: 533-547.

Aziz, J.J., C.J. Newell, M. Ling, and H.S. Rifai. 2003. Effective and eff cient LTM: Spatial/temporal data analysis and visualization. Paper read at Seventh International In Situ and On-Site Bioremediation Symposium, June 2003, at Orlando, Florida.

Beak, D.G., R.T. Wilkin, R.G. Ford, and S.D. Kelly. 2008. Examination of arsenic speciation in sulf dic solutions using X-ray absorption spectroscopy. Environmental Science and Technology 42, no. 5: 1643-1650.

Benner, S.G., C.M. Hansel, B.W. Wielinga, T.M. Barber, and S. Fendorf. 2002. Reductive dissolution and biomineralization of iron hydroxide under dynamic fow conditions. Environmental Science and Technology 36, no. 8: 1705-1711.

Bonneville, S., P. Van Cappellen, and T. Behrends. 2004. Microbial reduction of iron(III) oxyhydroxides: effects of mineral solubility and availability. Chemical Geology 212, no. 3-4: 255-268.

Bostick, B.C., and S. Fendorf. 2003. Arsenite sorption on troilite (FeS) and pyrite $\left(\mathrm{FeS}_{2}\right)$. Geochimica et Cosmochimica Acta 67 , no. 5: 909-921.

Burgess, W.G., and L. Pinto. 2005. Preliminary observations on the release of arsenic to groundwater in the presence of hydrocarbon contaminants in UK aquifers. Mineralogical Magazine 69, no. 5: 887-896.

Chiu, V.Q., and J.G. Hering. 2000. Arsenic adsorption and oxidation at manganite surfaces. 1. Method for simultaneous determination of adsorbed and dissolved arsenic species. Environmental Science and Technology 34, no. 10: 2029-2034.

Choi, S., P.A. O'Day, and J.G. Hering. 2009. Natural attenuation of arsenic by sediment sorption and oxidation. Environmental Science and Technology 43, no. 12: 4263-4269.

Christensen, T.H., P. Kjeldsen, P.L. Bjerg, D.L. Jensen, J.B. Christensen, A. Baun, H.J. Albrechtsen, and C. Heron. 2001. Biogeochemistry of landf 11 leachate plumes. Applied Geochemistry 16, no. 7-8: 659-718.

Christensen, T.H., P.L. Bjerg, S.A. Banwart, R. Jakobsen, G. Heron, and H.J. Albrechtsen. 2000. Characterization of redox conditions in groundwater contaminant plumes. Journal of Contaminant Hydrology 45, no. 3-4: 165-241.

Christensen, T.H., P. Kjeldsen, H.J. Albrechtsen, G. Heron, P.H. Nielsen, P.L. Bjerg, and P.E. Holm. 1994. Attenuation of land$\mathrm{f} 11$ leachate pollutants in aquifers. Critical Reviews in Environmental Science and Technology 24, no. 2: 119-202.

Cooper, D.C., A.L. Neal, R.K. Kukkadapu, D. Brewe, A. Coby, and F.W. Picardal. 2005. Effects of sediment iron mineral composition on microbially mediated changes in divalent metal speciation: Importance of ferrihydrite. Geochimica et Cosmochimica Acta 69, no. 7: 1739-1754.

Cozzarelli, I.M., B.A. Bekins, M.J. Baedecker, G.R. Aiken, R.P. Eganhouse, and M.E. Tuccillo. 2001. Progression of natural attenuation processes at a crude-oil spill site. 1. Geochemical evolution of the plume. Journal of Contaminant Hydrology 53, no. 3-4: 369-385.

Cummings, D.E., F. Caccavo, S. Fendorf, and R.F. Rosenzweig. 1999. Arsenic mobilization by the dissimilatory Fe(III)-reducing bacterium Shewanella alga BrY. Environmental Science and Technology 33, no. 5: 723-729.

deLemos, J.L., B.C. Bostick, C.E. Renshaw, S. Sturup, and X.H. Feng. 2006. Landf 11-stimulated iron reduction and arsenic release at the Coakley Superfund Site (NH). Environmental Science and Technology 40, no. 1: 67-73.
Demergasso, C.S., G. Chong, L. Escudero, J.J.P. Mur, and C. Pedros-Alio. 2007. Microbial precipitation of arsenic sulf des in Andean salt fats. Geomicrobiology Journal 24, no. 2: $111-$ 123.

Deschamps, E., V.S.T. Ciminelli, and W.H. Holl. 2005. Removal of $\mathrm{As}(\mathrm{III})$ and $\mathrm{As}(\mathrm{V})$ from water using a natural $\mathrm{Fe}$ and $\mathrm{Mn}$ enriched sample. Water Research 39, no. 20: 5212-5220.

Dixit, S., and J.G. Hering. 2003. Comparison of arsenic(V) and arsenic(III) sorption onto iron oxide minerals: Implications for arsenic mobility. Environmental Science and Technology 37, no. 18: 4182-4189.

Drewniak, L., A. Styczek, M. Majder-Lopatka, and A. Sklodowska. 2008. Bacteria, hypertolerant to arsenic in the rocks of an ancient gold mine, and their potential role in dissemination of arsenic pollution. Environmental Pollution 156, no. 3: 1069-1074.

Ghosh, A., M. Mukiibi, and W. Ela. 2004. TCLP underestimates leaching of arsenic from solid residuals under landf 11 conditions. Environmental Science and Technology 38, no. 17: 46774682.

Ghosh, R., W. Deutsch, S. Geiger, K. McCarthy, and D. Beckmann. 2003. Geochemistry, fate and transport of dissolved arsenic in petroleum hydrocarbon impacted groundwater. Paper read at Petroleum Hydrocarbons and Organic Chemicals in Groundwater, August 19-22, at Costa Mesa, California.

Glasauer, S., P.G. Weidler, S. Langley, and T.J. Beveridge. 2003. Controls on Fe reduction and mineral formation by a subsurface bacterium. Geochimica et Cosmochimica Acta 67, no. 7: 1277-1288.

Goldberg, S., and C.T. Johnston. 2001. Mechanisms of arsenic adsorption on amorphous oxides evaluated using macroscopic measurements, vibrational spectroscopy, and surface complexation modeling. Journal of Colloid and Interface Science 234, no. 1: 204-216.

Grenthe, I., W. Stumm, M. Laaksuharju, A.C. Nilsson, and P. Wikberg. 1992. Redox potentials and redox reactions in deep groundwater systems. Chemical Geology 98, no. 1-2: 131150.

Hering, J.G., and S. Dixit. 2005. Contrasting sorption behavior of arsenic(III) and arsenic(V) in suspensions of iron and aluminum oxyhydroxides. In Advances in Arsenic Research, ed. D. Vlassopoulos, L. Benning, X.G. Meng, and P.A. O'Day. Washington, DC: American Chemical Society.

Hering, J.G., and P.E. Kneebone. 2001. Biogeochemical controls on arsenic occurrence and mobility in water supplies. In Environmental Chemistry of Arsenic, ed. W.T. Frankenberger. New York: Marcel Dekker.

Heron, G., P.L. Bjerg, P. Gravesen, L. Ludvigsen, and T.H. Christensen. 1998. Geology and sediment geochemistry of a landf 11 leachate contaminated aquifer (Grindsted, Denmark). Journal of Contaminant Hydrology 29, no. 4: 301-317.

Hohn, R., A. Isenbeck-Schroter, D.B. Kent, J.A. Davis, R. Jakobsen, S. Jann, V. Niedan, C. Scholz, S. Stadler, and A. Tretner. 2006. Tracer test with $\mathrm{As}(\mathrm{V})$ under variable redox conditions controlling arsenic transport in the presence of elevated ferrous iron concentrations. Journal of Contaminant Hydrology 88, no. 1-2: 36-54.

Hug, S.J., and O. Leupin. 2003. Iron-catalyzed oxidation of arsenic(III) by oxygen and by hydrogen peroxide: $\mathrm{pH}$-dependent formation of oxidants in the Fenton reaction. Environmental Science and Technology 37, no. 12: 2734-2742.

Jambeck, J., K. Weitz, H. Solo-Gabriele, T. Townsend, and S. Thorneloe. 2007. CCA-treated wood disposed in landf lls and life-cycle trade-offs with waste-to-energy and MSW landf 11 disposal. Waste Management 27, no. 8: S21-S28. 
Jambeck, J.R., T. Townsend, and H. Solo-Gabriele. 2006. Leaching of chromated copper arsenate (CCA)-treated wood in a simulated monof 11 and its potential impacts to landf 11 leachate. Journal of Hazardous Materials 135, no. 1-3: 21-31.

Jing, C.Y., S.Q. Liu, M. Patel, and X.G. Meng. 2005. Arsenic leachability in water treatment adsorbents. Environmental Science and Technology 39, no. 14: 5481-5487.

Keimowitz, A.R., B.J. Mailloux, P. Cole, M. Stute, H.J. Simpson, and S.N. Chillrud. 2007. Laboratory investigations of enhanced sulfate reduction as a groundwater arsenic remediation strategy. Environmental Science and Technology 41, no. 19: 6718-6724.

Keimowitz, A.R., H.J. Simpson, M. Stute, S. Datta, S.N. Chillrud, J. Ross, and M. Tsang. 2005. Naturally occurring arsenic: Mobilization at a landf 11 in Maine and implications for remediation. Applied Geochemistry 20, no. 11: 1985-2002.

Khaitan, S., S. Kalainesan, L.E. Erickson, P. Kulakow, S. Martin, R. Karthikeyan, S.L.L. Hutchinson, L.C. Davis, T.H. Illangasekare, and C. Ng'oma. 2006. Remediation of sites contaminated by oil ref nery operations. Environmental Progress 25, no. 1: 20-31.

Kirk, M.F., T.R. Holm, J. Park, Q.S. Jin, R.A. Sanford, B.W. Fouke, and C.M. Bethke. 2004. Bacterial sulfate reduction limits natural arsenic contamination in groundwater. Geology 32, no. 11: 953-956.

Lee, M.K., J.A. Saunders, R.T. Wilkin, and S. Mohammad. 2005. Geochemical modeling of arsenic speciation and mobilization: Implications for bioremediation. In Advances in Arsenic Research, ed. D. Vlassopoulos, L. Benning, X.G. Meng, and P.A. O'Day. Washington, D.C.: American Chemical Society.

Lin, Z.X., and R.W. Puls. 2003. Potential indicators for the assessment of arsenic natural attenuation in the subsurface. Advances in Environmental Research 7, no. 4: 825-834.

Lovley, D.R. 1987. Organic-matter mineralization with the reduction of ferric iron-a review. Geomicrobiology Journal 5, no. 3-4: 375-399.

Lovley, D.R., E.J.P. Phillips, and D.J. Lonergan. 1989. Hydrogen and formate oxidation coupled to dissimilatory reduction of iron or manganese by Alteromonas putrefaciens. Applied and Environmental Microbiology 55, no. 3: 700-706.

Lovley, D.R., and E.J.P. Phillips. 1986a. Availability of ferric iron for microbial reduction in bottom sediments of the fresh-water tidal Potomac River. Applied and Environmental Microbiology 52, no. 4: 751-757.

Lovley, D.R., and E.J.P. Phillips. 1986b. Organic-matter mineralization with reduction of ferric iron in anaerobic sediments. Applied and Environmental Microbiology 51, no. 4: 683-689.

Manning, B.A., S.E. Fendorf, and D.L. Suarez. 2003. Arsenic(III) complexation and oxidation reactions on soil. In Biogeochemistry of Environmentally Important Trace Elements, ed. Y. Cai and O.C. Braids. Washington, D.C.: American Chemical Society.

Manning, B.A., S.E. Fendorf, B. Bostick, and D.L. Suarez. 2002. Arsenic(III) oxidation and $\operatorname{arsenic}(\mathrm{V})$ adsorption reactions on synthetic birnessite. Environmental Science and Technology 36, no. 5: 976-981.

Manning, B.A., and D.L. Suarez. 2000. Modeling arsenic(III) adsorption and heterogeneous oxidation kinetics in soils. Soil Science Society of America Journal 64, no. 1: 128-137.

McLean, J.E., R.R. Dupont, and D.L. Sorensen. 2006. Iron and arsenic release from aquifer solids in response to biostimulation. Journal of Environmental Quality 35, no. 4: 1193-1203.

McMahon, P.B., and F.H. Chapelle. 2008. Redox processes and water quality of selected principal aquifer systems. Ground Water 46, no. 2: 259-271.
Moghaddam, A.H., and C.N. Mulligan. 2008. Leaching of heavy metals from chromated copper arsenate (CCA) treated wood after disposal. Waste Management 28, no. 3: 628-637.

Mukherjee, A., and A.E. Fryar. 2008. Deeper groundwater chemistry and geochemical modeling of the arsenic affected western Bengal basin, West Bengal, India. Applied Geochemistry 23, no. 4: 863-894.

Mukhopadhyay, R., B.P. Rosen, L.T. Pung, and S. Silver. 2002. Microbial arsenic: From geocycles to genes and enzymes. FEMS Microbiology Reviews 26, no. 3: 311-325.

Newman, D.K., T.J. Beveridge, and F.M.M. Morel. 1997. Precipitation of arsenic trisulf de by Desulfotomaculum auripigmentum. Applied and Environmental Microbiology 63, no. 5: 2022-2028.

NRC. 2000. Natural Attenuation for Groundwater Remediation. Washington, D.C.: National Research Council, National Academy Press.

O'Day, P.A., D. Vlassopoulos, R. Root, and N. Rivera. 2004. The inf uence of sulfur and iron on dissolved arsenic concentrations in the shallow subsurface under changing redox conditions. Proceedings of the National Academy of Sciences of the United States of America 101, no. 38: 13703-13708.

Oremland, R.S., and J.F. Stolz. 2003. The ecology of arsenic. Science 300, no. 5621: 939-944.

Oscarson, D.W., P.M. Huang, W.K. Liaw, and U.T. Hammer. 1983. Kinetics of oxidation of arsenite by various manganese dioxides. Soil Science Society of America Journal 47, no. 4: 644-648.

Oscarson, D.W., P.M. Huang, and W.K. Liaw. 1981. Role of manganese in the oxidation of arsenite by fresh-water lake-sediments. Clays and Clay Minerals 29, no. 3: 219-225.

Pinel-Raffaitin, P., I. Le Hecho, D. Amouroux, and M. Potin-Gautter. 2007. Distribution and fate of inorganic and organic arsenic species in landf 11 leachates and biogases. Environmental Science and Technology 41, no. 13: 4536-4541.

Radloff, K.A., Z.Q. Cheng, M.W. Rahman, K.M. Ahmed, B.J. Mailloux, A.R. Juhl, P. Schlosser, and A. van Geen. 2007. Mobilization of arsenic during one-year incubations of grey aquifer sands from Araihazar, Bangladesh. Environmental Science and Technology 41, no. 10: 3639-3645.

Reisinger, H.J., D.R. Burris, and J.G. Hering. 2005. Remediating subsurface arsenic contamination with monitored natural attenuation. Environmental Science and Technology 39, no. 22: 458A-464A.

Rittle, K.A., J.I. Drever, and P.J.S. Colberg. 1995. Precipitation of arsenic during bacterial sulfate reduction. Geomicrobiology Journal 13, no. 1: 1-11.

Rittmann, B.E., R.G. Ford, R.T. Wilkin, J.W. Everett, and L. Kennedy. 2007. Monitored natural attenuation forum; MNA of metals and radionuclides. Remediation 18, no. 1: 121-129.

Roden, E.E. 2006. Geochemical and microbiological controls on dissimilatory iron reduction. Comptes Rendus Geoscience 338, no. 6-7: 456-467.

Roden, E.E. 2004. Analysis of long-term bacterial vs. chemical $\mathrm{Fe}(\mathrm{III})$ oxide reduction kinetics. Geochimica et Cosmochimica Acta 68, no. 15: 3205-3216.

Roden, E.E. 2003. Fe(III) oxide reactivity toward biological versus chemical reduction. Environmental Science and Technology 37, no. 7: 1319-1324.

Salmassi, T.M., K. Venkateswaren, M. Satomi, K.H. Nealson, D.K. Newman, and J.G. Hering. 2002. Oxidation of arsenite by Agrobacterium albertimagni, AOL15, sp nov., isolated from Hot Creek, California. Geomicrobiology Journal 19, no. 1: 53-66.

Saxe, J.K., E.J. Wannamaker, S.W. Conklin, T.F. Shupe, and B.D. Beck. 2007. Evaluating landf 11 disposal of chromated copper arsenate (CCA) treated wood and potential effects on 
groundwater: Evidence from Florida. Chemosphere 66, no. 3: 496-504.

Schwertmann, U., and R. Taylor. 1989. Iron oxides. In Minerals in Soil Environments, ed. J.B. Dixon and S.B. Weed. Madison, Wisconsin: Soil Science Society of America.

Scott, M.J., and J.J. Morgan. 1995. Reactions at oxide surfaces.1. Oxidation of As(III) by synthetic birnessite. Environmental Science and Technology 29, no. 8: 1898-1905.

Smedley, P.L., and D.G. Kinniburgh. 2002. A review of the source, behaviour and distribution of arsenic in natural waters. Applied Geochemistry 17, no. 5: 517-568.

Stollenwerk, K.G., and J.A. Colman. 2003. Natural remediation potential of arsenic-contaminated ground water. In Arsenic in Ground Water, ed. A.H. Welch and K.G. Stollenwerk. Boston: Kluwer Academic.

Suthersan, S., and J. Horst. 2008. Aquifer minerals and in situ remediation: The importance of geochemistry. Ground Water Monitoring and Remediation 28, no. 3: 153-160.

Townsend, T., T. Tolaymat, H. Solo-Gabriele, B. Dubey, K. Stook, and L. Wadanambi. 2004. Leaching of CCA-treated wood: implications for waste disposal. Journal of Hazardous Materials 114, no. 1-3: 75-91.

USEPA. 2007a. Monitored natural attenuation of inorganic contaminants in ground water: Technical basis for assessment. http:// www.epa.gov/ada/download/reports/600R07139/600R07139. pdf (accessed August 28, 2008).

USEPA. 2007b. Monitored natural attenuation of inorganic contaminants in ground water: Assessment for non-radionuclides including arsenic, cadmium, chromium, copper, lead, nickel, nitrate, perchlorate, and selenium. http://www.epa.gov/ada/download/reports/600R07140/600R07140.pdf (accessed August 28, 2008).

Vencelides, Z., O. Sracek, and H. Prommer. 2007. Modelling of iron cycling and its impact on the electron balance at a petroleum hydrocarbon contaminated site in Hnevice, Czech Republic. Journal of Contaminant Hydrology 89, no. 3-4: 270-294.

Wang, S.L., and C.N. Mulligan. 2006. Natural attenuation processes for remediation of arsenic contaminated soils and groundwater. Journal of Hazardous Materials 138, no. 3: 459-470.

Welch, A.H., D.B. Westjohn, D.R. Helsel, and R.B. Wanty. 2000. Arsenic in ground water of the United States: Occurrence and geochemistry. Ground Water 38, no. 4: 589-604.

Welch, A.H., and M.S. Lico. 1988. Aqueous geochemistry of ground-water with high-concentrations of arsenic and uranium, Carson River Basin, Nevada. Chemical Geology 70, no. 1-2: 19-19.
Welch, A.H., M.S. Lico, and J.L. Hughes. 1988. Arsenic in ground water of the Western United States. Ground Water 26, no. 3: 333-347.

Zobrist, J., P.R. Dowdle, J.A. Davis, and R.S. Oremland. 2000. Mobilization of arsenite by dissimilatory reduction of adsorbed arsenate. Environmental Science and Technology 34, no. 22: 4747-753.

Author's Note: The U.S. Environmental Protection Agency, through its Office of Research and Development, provided technical feedback to research supporting the findings in this article. This work has not been subjected to Agency review and therefore does not necessarily reflect the views of the Agency and does not represent guidance or policy on the part of the Agency, and no official endorsement should be inferred.

\section{Biographical Sketches}

Janet G. Hering, corresponding author, is the director of Eawag, Swiss Federal Institute of Aquatic Science \& Technology, Ueberlandstrasse 133, CH-8600, Duebendorf, Switzerland. When this work was performed, she was a professor at the Department of Environmental Science and Engineering, California Institute of Technology, Pasadena, California; janet.hering@eawag.ch.

Peggy A. O'Day is a professor at the School of Natural Sciences, University of California, Merced, 5200 N. Lake Rd., Merced, CA 95343.

Robert G. Ford, Ph.D., is a research scientist at USEPA, National Risk Management Research Laboratory, 26 West Martin Luther King Dr., Cincinnati, OH 45268.

Y. Thomas He, Ph.D., contributed to this work as a postdoctoral scientist at the Department of Environmental Science and Engineering, California Institute of Technology, 1200 E. California Blvd., MC 138-78, Pasadena, CA 91125.

Azra Bilgin, Ph.D., contributed to this work as a postdoctoral scientist at the Department of Environmental Science and Engineering, California Institute of Technology, 1200 E. California Blvd., MC 138-78, Pasadena, CA 91125.

$\boldsymbol{H}$. James Reisinger is CEO of Integrated Science \& Technology, Inc., 1349 Old Highway 41, Marietta, GA 30060.

David R. Burris is a consulting scientist at Integrated Science \& Technology, Inc., 228 Harrison Avenue (Suite 102), Panama City, FL 32401. 